\title{
RELATIONSHIP BETWEEN MANGROVE VEGETATION AND THE TOPOGRAPHY, HYDROLOGICAL REGIME IN HUNG HOA COMMUNE, VINH CITY, NGHE AN, VIETNAM
}

\author{
Tran Thi Tuyen ${ }^{1}$, Kazuya Takahashi ${ }^{1}$
}

\begin{abstract}
The study was conducted in a secondary mangrove forest, surrounding the shrimp pond area of Hung Hoa commune, Vinh City, Nghe An Province, Vietnam. Land height from datum line and mean inundated duration range from $1.1 \mathrm{~m}$ to $1.9 \mathrm{~m}$ and from 9.0 hours day-1 to 19.6 hours $d a y^{-1}$, respectively. The stand mainly contains three or more herbaceous species (associate species; Cyperus malaccensis, Acanthus spp. and one non-mangrove species; Phragmites australis) other than two woody species. Zones of C. malaccensis and Acanthus spp. Distributing is overlapped in height and mean inundated duration, ranging from $1.1 \mathrm{~m}$ to $1.4 \mathrm{~m}$, from 16.7 hours day ${ }^{-1}$ to 19.6 hours day $y^{-1}$ and from $1.2 \mathrm{~m}$ to $1.4 \mathrm{~m}$, from 16.7 hours day $y^{-1}$ to 18.7 hours day-1, respectively. The results of this study show that the close relationship between mangrove species and tidal regime and topography, should be considered carefully when mangrove restoration.
\end{abstract}

Keywords: Mangrove forest; Hung Hoa commune.

Received: December 11, 2019 Accepted: December 12, $2019 \quad$ Published on: December 20, 2019

\section{Introduction}

The mangrove ecosystem is significant as an ecological importance at coastal surrounding through providing natural resources. Mangroves are known to stabilize coastal sediments through their above-ground aerial root complex $[4,14]$. he plants in the mangroves have different adaptations to the terrain and tidal regime. It is necessary to consider carefully the relationship of topography, tides and related factors in the mangrove environment when people impact on the ecosystem $[5,11]$.

Hung Hoa commune, Vinh city, Nghe An province, is located at the estuary of the Lam River, flowing through North-Central Vietnam. Shrimp culture is one of the primary industries in this area. With the rapid expansion of shrimpculture ponds at the beginning of the 2000 s, the lagoon with mangrove forests had been decreased, which degraded regional ecosystem services. From 1982 to 2000, ca. 47,000 ha of

${ }^{1}$ School of Agriculture and Natural Resources,

Vinh University

Email: tuyentt@vinhuni.edu.vn the salted area had been reduced especially due to changing to shrimp-culture ponds, and ca. 1,000 ha of shrimp-culture ponds exist in Nghe An province (as of 2001), accounting for $0.4 \%$ of total shrimp-culture ponds in Vietnam [7]. Considering this matter, the central Government of Vietnam has launched a strategy of Green Economic Development in the Lam River watershed, including the estuary (Vietnam socio-economic development strategy 2011 2020). However, few concrete measures have been conducted. Secondary mangrove stand; Sonneratia caseolaris - Aegicerus corniculatum in the canal network adjacent to the shrimp-culture ponds at the Lam River estuary was surveyed. The main objective of this study is to elucidate the relationship between species distribution and flooded duration by brackish water to apply for designing of silvofishery systems to the shrimp-culture ponds. 


\section{Methodology}

\subsection{Study area}

Secondary mangrove forest in the study site is dominated by S. caseolaris and A. corniculatum in the canal network adjacent to the shrimp-culture ponds at the Lam River estuary in Hung Hoa commune, Nghe An province, Vietnam (Fig. 1). It is regularly flooded by brackish water; the estimated mean highest spring tide and mean lowest spring tide in 2019 are $2.7 \mathrm{~m}$ and $0.5 \mathrm{~m}$, respectively (Center for Oceanography 2018) [1]. This canal network has four gates to control water input and output from/to the Lam River for irrigation and flood prevention. The Lam River is a trans-boundary river. It is originated in Laos and flows mainly through Nghe An province, Vietnam into the Gulf of Tonkin (background of key river basins, World Bank document) [3]. The climate of Nghe An province is affected by North-East monsoon; annual average temperature is $24.6^{\circ} \mathrm{C}$; the warmest month is June; $30.1^{\circ} \mathrm{C}$ in average, the coldest month is January; $18.3^{\circ} \mathrm{C}$ in average and annual average rainfall is $1,753 \mathrm{~mm}$ year-1; minimum precipitation month is March; $48 \mathrm{~mm}$ in average, maximum precipitation month is September; $445 \mathrm{~mm}$ in average [2].
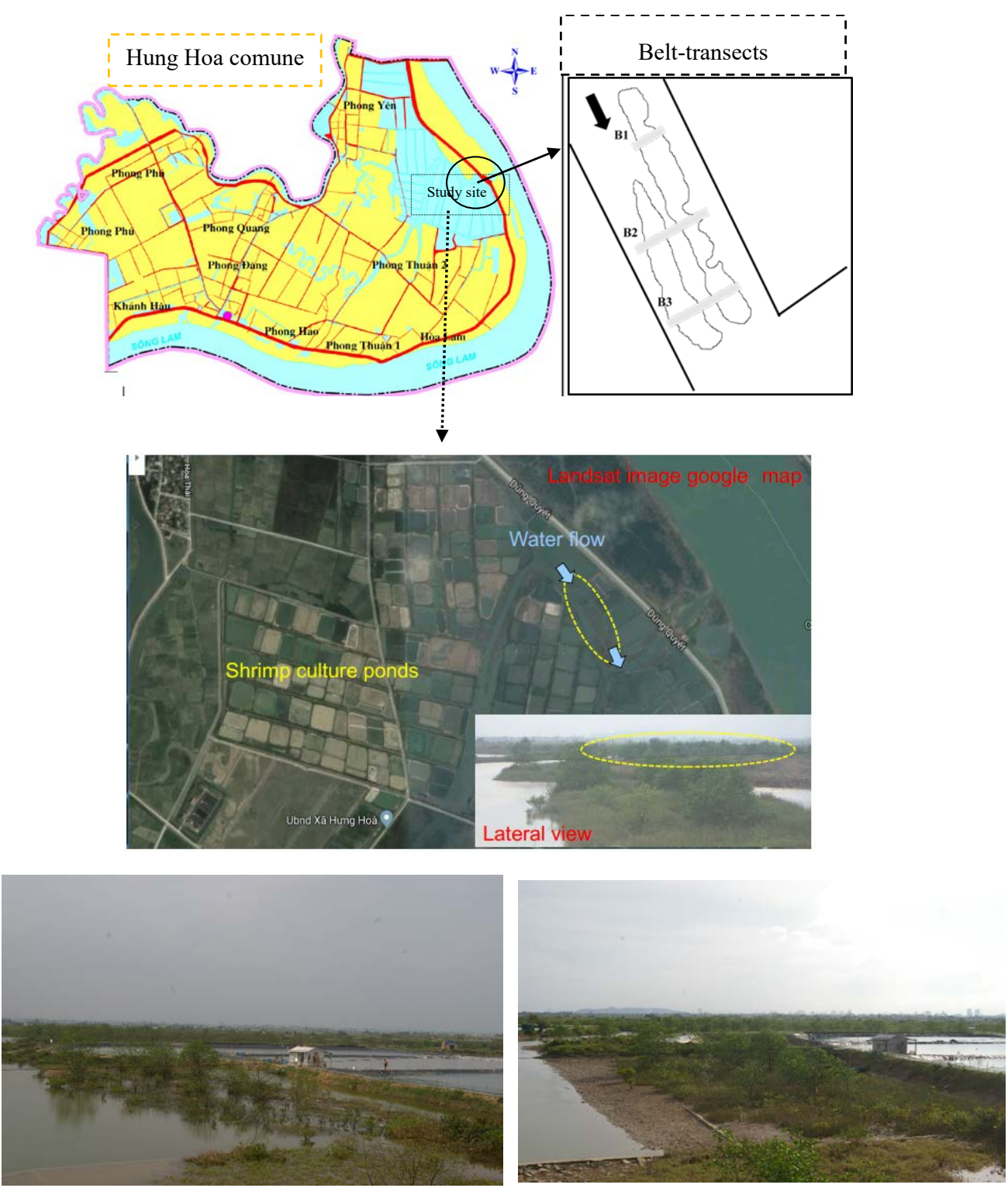

Fig. 1. Study area and location of belt-transects 


\subsection{Field survey}

To understand vegetation gradients corresponding to the land height from datum line and inundation duration, three belts; B1-B3 (B1: $18^{\circ} 41^{\prime} 27^{\prime \prime} \mathrm{N}-105^{\circ} 45^{\prime} 32^{\prime \prime} \mathrm{E}-18^{\circ} 41^{\prime} 26^{\prime \prime} \mathrm{N}$,

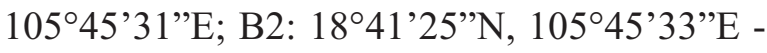
$18^{\circ} 41^{\prime} 23^{\prime \prime} \mathrm{N}, 105^{\circ} 45^{\prime} 32^{\prime \prime} \mathrm{E}$; B3: 18 41'23'”, $\left.105^{\circ} 45^{\prime} 34^{\prime \prime} \mathrm{E}-18^{\circ} 41^{\prime} 21^{\prime \prime} \mathrm{N}, 105^{\circ} 45^{\prime} 32^{\prime \prime} \mathrm{E}\right)$ were selected in the mangrove stands (Fig. 1). At each belt, the centerline was set up horizontally. The height from the centerline to the land surface was measured every $2.5 \mathrm{~m}$ if water body existed water depth was also recorded. After measuring height, it was converted to the land height based on the relationship between real water depth measured and tide height (Center for Oceanography 2018). For the understanding of vegetation gradients, 2 $\mathrm{m}$ bars were set up perpendicular to the centerline for both sides every $5 \mathrm{~m}$, and all the species occurring and their land coverages by the crowns of trees or plants body of herbs were recorded in the $4 \times 5 \mathrm{~m}$ rectangular. Belt-transects surveys were conducted on June $9^{\text {th }}$ and July $12^{\text {th }}-14^{\text {th }}$, 2019.

\subsection{Inundated duration}

Since the vegetation occurs ranging approximately from $1.0 \mathrm{~m}$ to $2.0 \mathrm{~m}$ in land height, average inundated duration per day of this range in unit of $0.1 \mathrm{~m}$ was estimated by comparing the land height with change in tide level at Cua Hoi; $18^{\circ} 48^{\prime} \mathrm{N}, 105^{\circ} 46^{\prime} \mathrm{E}$ (Center for Oceanography 2018). i.e., cumulative inundated time for each land height in the year 2019 divided by 365 days (Fig. 2).

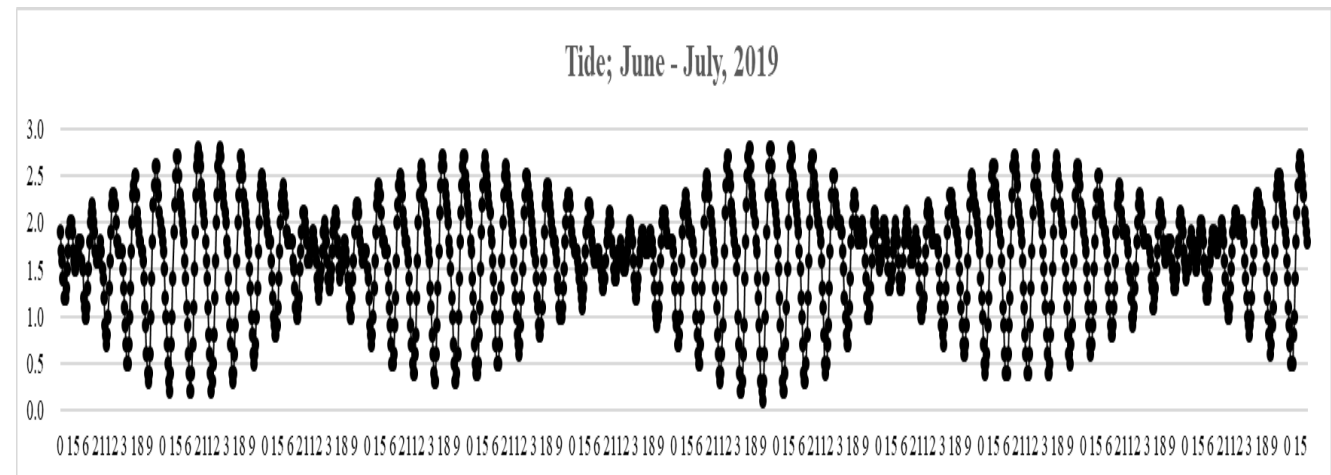

Fig. 2. Tidal change at the Lam River estuary (Cua Hoi: $18^{\circ} 48^{\prime} \mathrm{N}, 105^{\circ} 46^{\prime}$ E): June - July 2019, cited from Center for Oceanography 2018

\section{Results}

\subsection{Vegetation distribution}

In the belt-transects $B 1$ :

Out of the five distribution species, Aegicerus is the dominant species in this section. They are distributed on the highest terrain (floating lands). The highest density is $35 \mathrm{~m}$ from the starting point to the left, accounting for 40 percent (Fig. 3 ). However, the further to the left, the species occurrence decreases. At a distance of $40 \mathrm{~m}$ from the starting point, the coverage density of this species is only 5 percent. In contrast, Sypeus is scattered in the left-hand survey points but dominant in the left survey points. At a distance of $40 \mathrm{~m}$, the thickest distribution density, accounted for 30 percent. Besides, Phragmites is also a common species in this complex. At $25 \mathrm{~m}$, the highest coverage density, reaching 40 percent. 


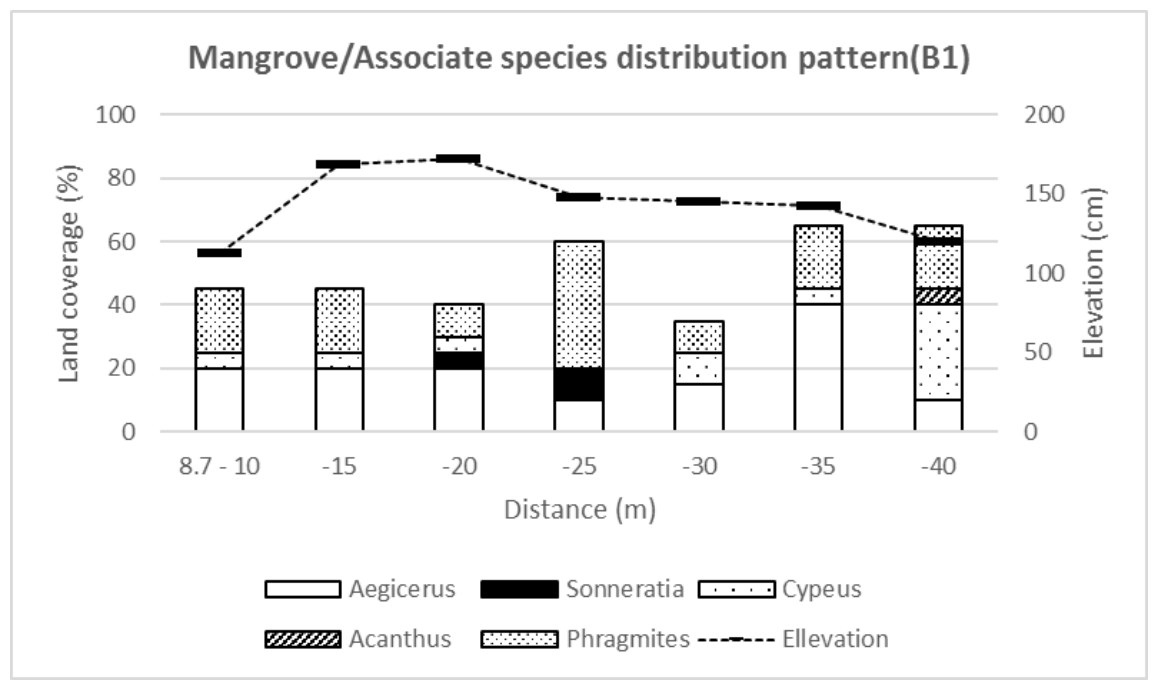

Fig. 3. The distribution of species in B1

In the belt-transects B2: On the left-side Phragmites, neither mangrove nor associate species, is growing at the almost same average water level. On the right-side A. corniculatum is dominant. The highest density is $10-15 \mathrm{~m}$ from the starting point to the right, accounting for 90 percent (Fig. 4). The appearance decreases gradually along the left slice and disappears from a distance of $40 \mathrm{~m}$. Meanwhile, the density of Aegicerus increases and changes the dominant position of Phragmites. These two species have common characteristics that are distributed in high terrain. The opposite of them is Aegicerus, which is always distributed in low terrain, although the density of coverage also increases towards the left of the transect.

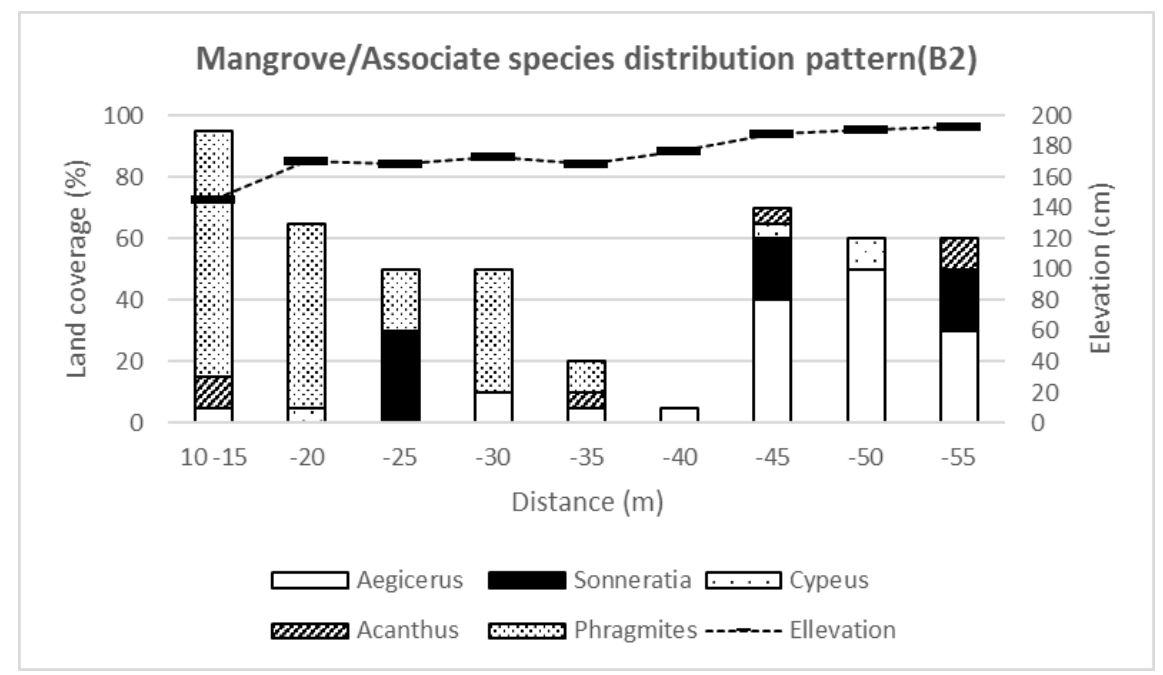

Fig. 4. The distribution of species in B2

In the belt-transects B3: On the left-side A. caseoralis and A. corniculatum with Acanthus corniculatum with C. malaccensis, which has a spp., which grow on ca. $10-20 \mathrm{~cm}$ higher than correlation with elevation inland coverage $(\mathrm{r}=$ the land level of C. malaccensis growing (Fig. $0.91 \mathrm{p}<0.01)$ is dominant, on the right-side $\mathrm{S}$. 5). 


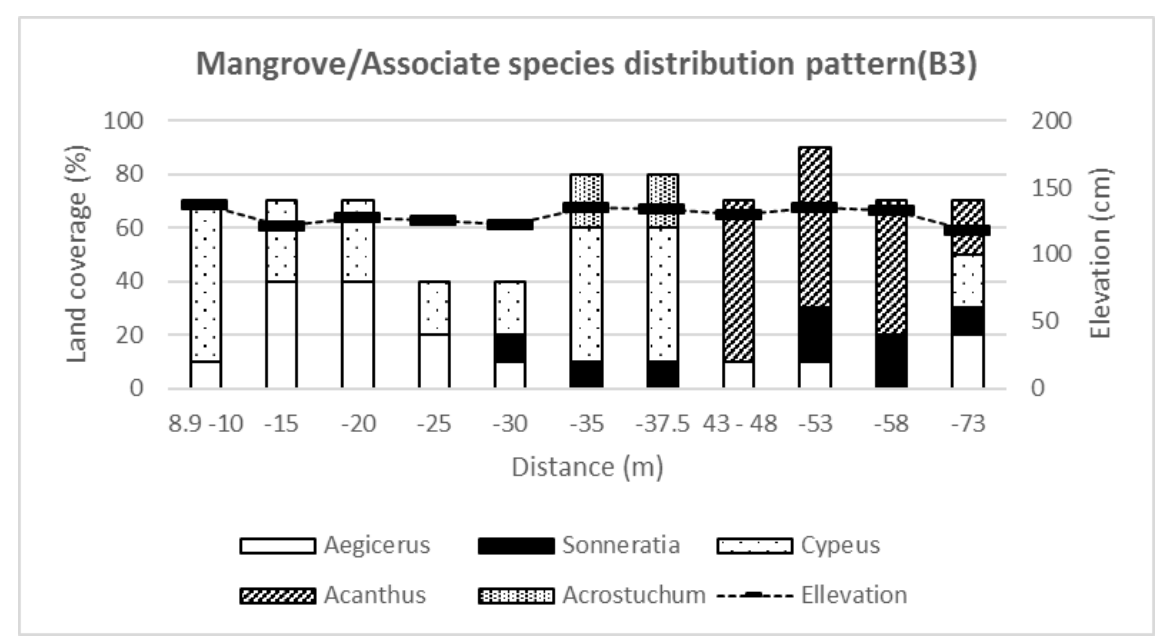

Fig. 5. The distribution of species in B3

\subsection{Relationship between species distribu- tion and land height, inundated duration}

Land height data on A. corniculatum, S. caseolaris, C. malaccensis, Acanthus spp. Moreover, P. australis distributing was plotted in Fig. 6, and the distribution pattern of each species with inundated duration (Fig.7) was summarized in Table 1. Distribution range inland height of these five species are not significantly different, but $\mathrm{P}$. australis, which is neither mangrove nor associate species [8], tends to distribute intensively at $1.4-1.7 \mathrm{~m}$ inland height, inundation duration of 12.7-16.7 hours day ${ }^{-1}$. Land heights of other four species inhabiting range wider than one of $P$. australis, from 1.1 to $1.9 \mathrm{~m}$ in land height, inundation duration of 9.0-19.6 hours day ${ }^{-1}$, those species except for A. corniculatum, intensively distribute slightly lower zones, especially S. caseolaris intensively distributes from $1.3 \mathrm{~m}$ to $1.4 \mathrm{~m}$ in land height, inundation duration of 16.7 -17.7 hours day ${ }^{-1}$. Herbaceous species; C. malaccensis and Acanthus spp. tend to intensively distribute on the lower zones than two woody mangrove species, from $1.1 \mathrm{~m}$ to $1.4 \mathrm{~m}$ in land height, inundation duration of 16.7-19.6 hours day $^{-1}$ and from $1.2 \mathrm{~m}$ to $1.4 \mathrm{~m}$ in height, inundation duration of 16.7 - 18.7 hours day ${ }^{-1}$, respectively. The bottom line of the intensive distribution zone of Acanthus spp. is shifted $0.1 \mathrm{~m}$ higher than one of $\mathrm{C}$. malaccensis.

In the zone of $1.1-1.4 \mathrm{~m}$ inland height equivalent to B3 land height, land cover by C. malaccensis is correlated with land height; $r=0.91$, $\mathrm{p}<0.01$, but one by Acanthus spp. is not correlated with land height; $p=0.09$ (Fig. 7).

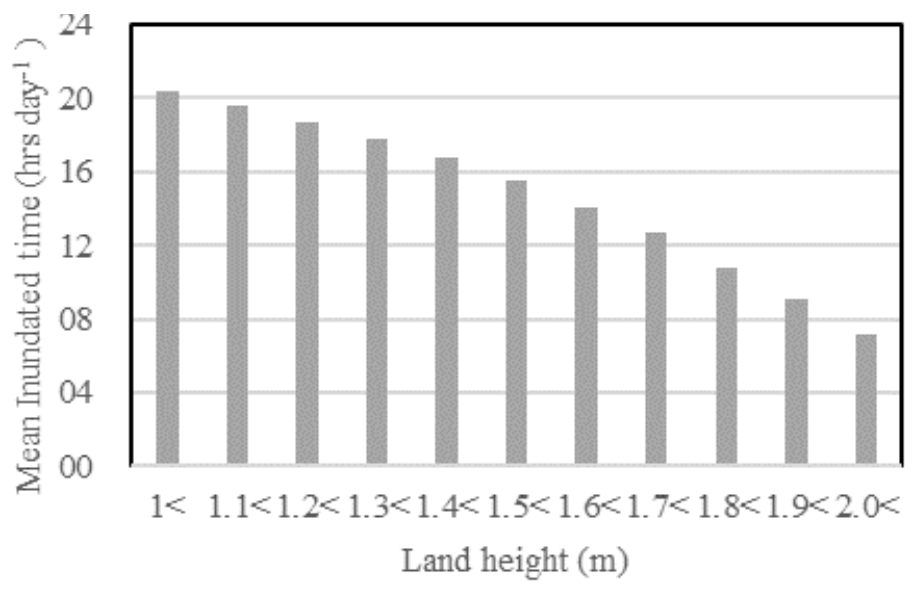

Fig. 6. Inundated duration at each land height 
Table 1. Summary of the distribution pattern of five species

\begin{tabular}{lccccc}
\hline \multicolumn{5}{l}{ Species } & \multicolumn{5}{c}{ Land height From DL $(\mathrm{m})$} & $\begin{array}{c}\text { Mean } \\
\text { inundated } \\
\text { duration } \\
\left.\text { (hrs day }{ }^{-1}\right)\end{array}$ \\
\hline A. corniculatum & 1.1 & 1.9 & 1.5 & $\begin{array}{l}\text { Melatively } \\
\text { homogenous }\end{array}$ & $9.0-19.6$ \\
S. caseolaris & 1.2 & 1.9 & 1.5 & $1.3-1.4$ & $16.7-17.7$ \\
C. malaccensis & 1.1 & 1.9 & 1.4 & $1.1-1.4$ & $16.7-19.6$ \\
Acanthus spp. & 1.2 & 1.9 & 1.5 & $1.2-1.4$ & $16.7-18.7$ \\
P. australis & 1.1 & 1.7 & 1.5 & $1.4-1.7$ & $12.7-16.7$ \\
\hline
\end{tabular}

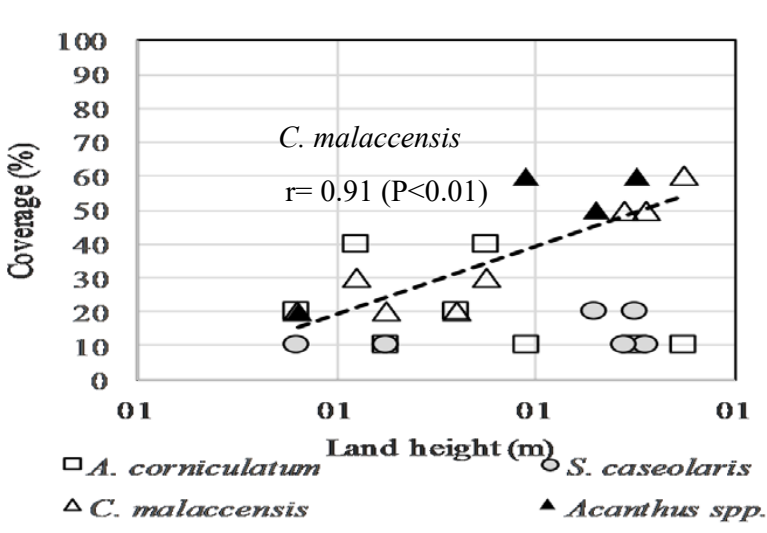

Fig. 7. Land height vs. coverage

\section{Conclusions}

S. caseolaris - A. corniculatum stand in the study site is the tide-dominated type of mangrove forest (Woodroffe 1992), regularly flooded by brackish water except for the gate being operated. Its land height ranges from $1.1 \mathrm{~m}$ to $1.9 \mathrm{~m}$, the mean inundated duration is $9.0-19.6$ hours day ${ }^{-1}$, and the mean water depth at spring tide is $0.81 .6 \mathrm{~m}$. It includes non-mangrove/associate species; P. australis being distributed intensively at MWL; $1.7 \mathrm{~m}$. S. caseolaris is typical mangrove species at river estuaries [5] in South East Asia, often with A. corniculatum [8] in North Central Vietnam.

The stand includes two or more herbaceous mangrove/associate species; C. malaccensis; associate species and Acanthus spp.; mangrove spp [8]. Their intensive distribution zones are overlapped. Mean inundation duration and mean water depth at spring tide of C. malaccensis are 16.7-19.6 hours day ${ }^{-1}$ and 1.3-1.6 m, respectively. While ones of Acanthus spp. are 16.7 18.7 hours day ${ }^{-1}$ and $1.3-1.5 \mathrm{~m}$, respectively. The previous study from Can Gio, Vietnam reported that Acanthus ebracteatus forms community with C. malaccensis and other species at the zone flooded by tides $1.5-2.0 \mathrm{~m}$ in height [6], corresponding to the observation in the study site. In the intensive distribution zone of $\mathrm{C}$. malaccensis; $1.1-1.4 \mathrm{~m}$ inland height, expansion of the habitat area along with increasing of land height was observed; $r=0.91, p<0.01$. Neither mangrove nor associate species, is growing at the almost same average water level.

\section{References}

1. Center for Oceanography (2018), Cua Hoi. In Tide tables 2019 (1); Ed. Quang D.N.; Publishing house of natural science and technology: 18 Hoang Quoc Viet, Cau Giay, Hanoi, Vietnam, 93-117.

2. Climate Vinh (2019), en.climate-data.org. (Accessed on 29 August 2019).

3. Clough, B., Johnston D., Xuan, T.T., Phillips, M., Pednekar, S.S., Thien, N.H., Dan T.H., Thong. P.L., (2002), Silvofishery Farming Systems in Ca Mau Province, Vietnam. In Report prepared under the World Bank, NACA, WWF and FAO Consortium Program on Shrimp Farming and the Environment. Work in Progress for Public Discussion; Published by the Consortium; pp. 73. 


\section{BÀI BÁO KHOA HỌC}

4. Department of Environment and Energy, Australia (2016), Coastal wetlands -mangroves and saltmarshes. environment.gov.au (Accessed on 19 June 2019).

5. Khoon, G.W., Aksornkoae, S., Tri, N.H., Vongwattana, K., Fan, H., Santoso, N., Barangan, F., Havanond, S., Sam, D.D., Pernetta, J., (2004), Inundation regime. In mangrove in the South China Sea; UNEP/GEF Project Co-ordinating Unit, United Nations Environment Programme: UN Building, $9^{\text {th }}$ Floor Block A, Rajdamnern Avenue, Bangkok 10200, Thailand; 6.

6. Hong, P.N., (2000), Effects of mangrove restoration and conservation on the biodiversity and environment in Can Gio district, Ho Chi Minh City Phan Nguyen Hong, International Workshop Asia-Pacific Cooperation on Research for Conservation of Mangroves, 26-30 March, 2000 -Okinawa, Japan, pp. 14.

7. Phuong, V.T., (2014a), Geographical distribution of mangrove forest in Viet Nam. In national report on mangroves in South China Sea Vietnam; Research Centre for Forest Ecology and Environment: Dong Ngac, Tu Liem, Hanoi, Viet Nam, pp. 1-4.

8. Phuong, V.T., (2014b), Species distribution and formation. In national report on mangroves in South China Sea Vietnam; Research Centre for Forest Ecology and Environment: Dong Ngac, Tu Liem, Hanoi, Viet Nam, pp. 5-14.

9. Santen, P.V., Augustinus, P.G.E.F., Janssen-Stelder, B.M., Quartel, S., Tri, N.H. (2017), Sedimentation in an estuarine mangrove system. Journal of Asian Earth Science, 29, 566-575.

10. Syaiful, E., Mohammad, R.R., Iskhaq I., Andy, M., (2016), Community-based mangrove forests conservation for sustainable fisheries. Journal Silvikultur Tropika, 7 (3), 42-47.

11. Farid, D.G., Kairo, J.G., Bondt, R.D., Koedam, N., (2007), Pneumatophore height and density in relation to micro-topography in the grey mangrove Avicennia marina Belgian Journal of Botany, 140 (2), 213-221. 